\title{
Literacy Under Authority: The Mongolian Cultural Campaigns
}

\author{
Marzluf, Phillip
}

\begin{abstract}
In the 1950s and 1960s, the Cultural Campaigns in the Mongolian People's Republic, consisting of hygiene, health, literacy, and ideology goals, mobilized pastoral Mongolians and consolidated the authority of the socialist Mongolian People's Revolutionary Party to induce a new social order, way of living, and modern subjectivity. Bringing together social definitions of literacy, theories about authority, and histories of mass literacy campaigns, this study demonstrates how the Revolutionary Party deployed technologies of power to represent and deliver literacy and the other Cultural Campaign goals to semi-nomadic pastoralists. Narratives from the University of Cambridge Oral History of Twentieth Century Mongolia (2013) document the ways in which the socialist Mongolian state infiltrated the private spaces of Mongolians, categorized them and made them a part of the public record, and shaped their attitudes towards reading and writing. These narratives also suggest the existence of subtle, muted responses that challenged the authority of the Revolutionary Party.
\end{abstract}

Keywords: Mongolia, Cultural Campaign, authority, literacy campaigns, literacy, technologies of power, hygiene 


\section{Literacy under Authority: The Mongolian Cultural Campaigns}

For the purposes of this article, literacy is defined as a social practice (Barton and Hamilton 1998), which is composed of observable activities, events, and activities that pertain to reading and writing in some way and, moreover, by unobservable cultural models or ideologies shaped by institutional, political, economic, technological, and cultural forces and flows (Barton and Hamilton 1998; Gee 2012; Heath 1983; Street 1985, 1995). As James Gee (2012) describes in his theory of Discourses, a literacy becomes a particular way of doing social action and performing an identity within a particular socially- and historically-situated community. Literacy is not, in other words, merely the school-sanctioned skill of encoding and decoding written symbols, a cognitive skill that occurs outside of identity formation and independent of social structures (Graff 2011). Literacy has political potentials and ideological consequences.

When viewed though this social theoretical lens, literacy becomes a highly generative historical and cultural variable. By focusing on these observable, micro, if not oftentimes mundane, literacy-related events and activities, Asian Studies scholars can examine the dominant, official, and elite structures or groups that authorize or privilege certain literacy practices and legitimate themselves by controlling or restricting access to particular activities and events, shaping to some extent the cultural models, the assumptions and attitudes about literacy, and, consequently, the range of possible subjectivities. By controlling these functions of or strategies related to literacy, these states, groups, or elite individuals, in turn, maintain and legitimate their authority, making their power appear natural, right, and inevitable (Best 2002). According to Anthony Giddens (1985) and James Scott (1998), the authority of the modern nation-state both bases itself on and flows through "strategies of control," "forms of domination," and "technologies of power," all different ways of accounting for how states 
enforce the authority of their rule through non-violent means. For this article, literacy takes precedent, both as a particular "technology of power" in its own right as well as a technology that enables state administrators to better categorize, normalize, and homogenize their subjects, making the population more governable (Foucault 1991) or, in Scott's (1998) terminology, to make subjects more "legible," more visible and easy to control. As a form of state power, literacy may be non-violent, yet we need to be cautious of treating literacy as an innocent technology, immune to coercion and violence. Indeed, the canonical Weberian distinction between authority and coercion (Best 2002) becomes less helpful when adopting a social literacy perspective. Coercion and violence may be lurking nearby, in the shape of shaming, observing, homogenizing, categorizing, excluding, and censoring (Graff 1979; Stuckey 1990). Though, obviously, literacy may not possess the terrifying force that marks the eruptions of state violence, Giddens $(1985,9)$ reminds us that quietly terrifying forms of power can dominate a broad scope of society, "running silently through the repetition of institutional practices."

Many examples exist of this articulation between state authority and literacy. Christopher Connery $(1999,43)$, for instance, describes the Qin-era book burnings not as anti-textual movements but as attempts to control teaching outside of the emperor's central power and thus to control the circulation of and access to texts (see Bazerman and Rogers 2007, 152). During the Qing dynasty, the emperors' appeals to Manchu elites and warriors to return to written Manchu and traditional instructional practices suggest a crisis of authority and anxiety over Han Chinese dominance — an anxiety that revealed itself earlier in Manchu multilingual policies (Crossley 1994, 347, 363). In the twentieth century, the Latinization script reform movements and literacysanitary campaigns in the Central Asian Soviet Republics have been examined as a conflict between the nascent Soviet authority and the Arabic-script-based scribal authority of Muslim 
clerics (Crisp 1989; Smith 1998). In the second half of the twentieth century, the centralized states and nascent socialist governments in China, Vietnam, and the Lao People's Democratic Republic demonstrated their authority through highly efficient and mass literacy campaigns (Rawski 1979; see Arnove and Graff 1987). Leaders of these twentieth-century campaigns exploited literacy as a symbol of equality, economic progress, social development, access to science and technology, and other social goods. Although historians of literacy, notably Harvey Graff (1979), contest such causal links between literacy and development, the rhetorical uses and consequences of literacy for legitimating Asian modern states provide fruitful opportunities for Asian Studies researchers, compelling them to de-emphasize the official discourses circulating around and through literacy. Rather, researchers can examine the ways in literacy has operated to legitimate states, shape attitudes towards the public sphere, and both produce and limit potential subjectivities.

The Cultural Campaigns (Soyolin Dovtolgoo) conducted by the Mongolian People's Revolutionary Party in the late 1950s and throughout the 1960s serves as an excellent case for exploring the relations between authority and literacy. Using the University of Cambridge Oral History of Twentieth Century Mongolia (2013), this article demonstrates how the Cultural Campaigns amplified earlier literacy development in the Mongolian People's Republic. By the end of the Cultural Campaigns, the Revolutionary Party and its allied international Soviet organizations successfully transformed the discourse and cultural models associated with literacy and attitudes towards formal education. Literacy and the acculturation of children were no longer considered the responsibility of the Mongolian home or local region; moreover, there were few, if any, educational and cultural alternatives outside of the Revolutionary Party, its allied Soviet organizations, and the socialist Mongolian government (Marzluf 2015). The destruction of the 
Tibetan Buddhist Church, the only dominant cultural and educational sponsor left to compete with the symbols and metanarratives of the early socialist Mongolian state, led in part to the Cyrillic script reforms in the early 1940s, the formalization of mass education, and the Cultural Campaigns themselves (Kaplonski 2014; Morozova 2009). Without the alternatives of the Mongolian home and the Buddhist temple, literacy became an increasingly centralized, authoritarian, and monological government and party project. Stated differently, the sacred sphere of the Buddhist Church and the intimate, private sphere of the home were subsumed by the "public" sphere of the socialist Mongolian state-yet, it was a highly orchestrated, closed, and univocal public. The socialist state further legitimated itself through statistical representations that reported tremendous gains as well as by appeals to Soviet and international institutions such as UNESCO, which awarded, in 1970, the inaugural Nadezhda K. Krupskaya Literacy Prize to the Language and Literature Institute of the Mongolian Academy of Sciences.

We need to be wary of simplifying the relationship of literacy with authority, however. Instead of bracketing literacy off as a unidirectional and hierarchical power, transmitted from the centralized state apparatus to pacify its subjects, we can examine literacy as constituted by what Scott (1998) describes as high-modernist strategies that are coordinated along with the other three main goals of the Cultural Campaigns: hygiene, health, and Marxist-Leninist ideology. In addition to the Cultural Campaign goals themselves, other massive social and economic changes occurred in the second half of the twentieth century, including the collectivization of the pastoral economy and the urbanization of the countryside (Humphrey and Sneath 1999); the formalization of the educational system under a Soviet model; the rise of a documentarian society and the need for "paperwork careers" (bichig tsaasni ajil) (see Lewin 1994, 237-39); the inward flow of Russian and Soviet terminology and cultural forms; as well as, finally, new 
electronic technologies, including radio, documentary and feature films, and television (Morozova 2002; 2009). Unfortunately, it is beyond the scope of this article to make rich intersections with these other cultural and social forces and flows. What is important to remember is what was at stake: the authority of the Mongolian socialist state rested, in part, on its ability to promote a new subjectivity, a modern way of living and being. Despite its attempts to homogenize this subjectivity—in the shape of the New Soviet Man, for instance (Cheng 2008) - and limit potential alternatives, this political project was unable to control completely how these subjectivities were taken on, adapted, or, for that matter, subtly resisted (Scott 1992).

\section{Literacy Campaigns in the Twentieth Century}

In National Literacy Campaigns, Robert Arnove and Harvey Graff $(1987,2)$, as well as their contributors, demonstrate how twentieth-century revolutionary governments deployed literacy campaigns to "establish a moral or political consensus," define a new nation-state, compel people into "more comprehensive political and/or religious communities," and create "a more moral society or a more stable political order." Arnove and Graff are interested, in other words, in how governments' official representations of literacy and mass literacy campaigns work rhetorically to legitimate new social orders and subjectivities. On the one hand, governments may package literacy as an individual, apolitical, neutral, and autonomous skill, one that helps legitimate their appeals to social equality and democratic participation; on the other hand, literacy is firmly tied to the goals of governmentability, social control, observation, and regulation (Arnove and Graff 1987, 8). When examined from this perspective, literacy becomes another strategy for revolutionary state administrators to control, categorize, and make more visible, in terms of the public record, populations that are semiotically or physically distant from governing centers (Scott 1998). 
Given the direct influence of the Soviet Union on the literacy cultural models and the literacy institution building of Mongolia and the Central Asian republics, it is necessary to pay attention to Soviet literacy and language planning and its relationship to Soviet state metadiscourse. The Soviet literacy campaigns of the 1920s and 1930s had several prerevolutionary precedents, including, at the start of the 1890s, a national literacy campaign, which was conducted as an appeal to modernization and as a response to European elites who considered Russia to be backwards (Eklof 1987, 125-126). In early revolutionary Soviet Russia, according to Ben Eklof $(1987,132)$, literacy embodied "militarization, brutality, siege mentality, and habits of command and compulsion." Literacy was a "campaign," in the military sense of the term, and became, during Stalin's First Five-Year Plan, a militarized instructional force. Taught quickly and efficiently by way of authoritarian decrees and "Cultural Soldiers" from the Young Communist League brigades at "illiteracy liquidation centers" (Brooks 2000), these Stalinist literacy campaigns became a form of legitimate state violence, similar to the forced migration of ethnic groups, industrialization, urbanization, collectivization, and violent anti-kulak and antireligious movements (Eklof 1987, 139-140; Lewin 1994, 219-220).

At the same time as these transformations, Soviet linguists were shaping a new Russian language, which would enable new ways of social interaction and make Soviet citizens more reliant on the printed word (Gill 2011). Michael Smith $(1998,103)$, for example, summarizes the work of early Soviet linguists as those who "appreciated scripts and grammars as means to ennoble the speech patterns of the common people in an encoded vernacular, to discipline them within a language of state discourse, [and] to raise them up to a greater historical standard." The Soviet press became the most important literacy resource for the Soviet Union, codifying new political terminology and constructing a language for communist party "insiders" (Brooks 2000, 
12-13). Importantly, Soviet Russian linguists and language planners exported their theories, policies, and practices to Central Asia and Mongolia, endorsing an international Soviet identity and appeals to linguistic modernization and efficiency, one that would first be expressed through Latinization movements and then, after 1938, by Cyrillicization (Crisp 1989; Smith 1998).

Mongolian Revolutionary Party elites and government ministry administrators, likewise, adopted similar Soviet terminology, organizations, texts, and pedagogical methods, establishing the tremendous Russian Soviet influence upon twentieth-century Mongolian conceptions of literacy and education. According to the historian, Sh. Natsagdorj $(1981,73)$, the Revolutionary Party, at the creation of the new socialist Mongolian state, focused on the elimination of illiteracy, a movement symbolizing for the purposes of the Marxist-Leninist metanarrative both an eradication of pre-revolutionary economic oppression as well as a surge in cultural activity. Throughout the 1920s and 1930s, the Revolutionary Party and the Ministry of Enlightenment (Gegeerliin Yam) declared several ceremonial pronouncements and practical polices to mobilize party members, Union of the Revolutionary Youth members, and other state employees, both in Ulaanbaatar and the countryside, against illiteracy. In 1929, for example, the Central Committee of the Revolutionary Party sponsored the first conference to explore the issues around literacy instruction, from out of which emerged the first of many large-scale, centralized literacy instructional plans: in this case, 300 teachers from primary- and middle-level schools, teacher preparatory schools, military schools, and the Union of Revolutionary Youth were charged with establishing two-month schools throughout all of the countryside (Natsagdorj 1981, 76). In that same year, the Illiteracy Eradication Union was formed by the Ministry of Enlightenment, which emphasized a closer-knit system of learning cells (ü̈̈r), circles (bülgem), committees (khoroo), and councils (zövlöl) (see Kaplonski 2014, 74-75). In Ulaanbaatar, for instance, there were 53 
literacy cells active and more than 2000 people studying at various organizational levels (Natsagdorj 1981, 77). In addition to the printing and distribution of newspapers, other strategies to distribute literacy instruction were established, such as reading rooms, propaganda-based red gers, and ideology lectures.

In the early 1930s, the precursor of the Cultural Campaigns, the Ikh Jagsaal, was initiated. Those who were illiterate were registered officially and plays were staged to dramatize the benefits of literacy (Natsagdorj 1981, 78). Each literate member of the Revolutionary Party, the Union of the Revolutionary Youth, and the military were instructed to tutor two illiterate individuals. In 1931 and 1932, 304 teachers were trained to teach the new Latin script using the short-term, small-group "circle" method of instruction (Natsagdorj 1981, 79). In 1932, as a part of the more gradual and less radical "New Turn" policy endorsed by the Revolutionary Party (see Bawden 1968), more teacher training, enhanced teaching methodology, and curricula for illiterate and semi-illiterate learners (Natsagdorj 1981, 80) were advocated. The Ministry of Education sponsored six-month courses, which met each week two or three times, for instruction in the traditional Mongol Bichig and Latin scripts. In these longer-term courses, students were expected to not only learn how to read and write, but to take notes, write letters, apply different reading methods, and learn basic arithmetic (Natsagdorj 1981, 81). In the latter 1930s, there was more production of literacy learning aids, including alphabet books and readers, alphabet wall charts, and individual, cut-up letters for adults (Natsagdorj 1981, 85). 45,000 copies of a Latinbased People's Reader were printed in 1938, and an additional 65,000 copies the following year (Rinchinsambuu 1963). In 1939, 30,000 copies of the Alphabet for Adults, which assisted instruction in the traditional Mongol Bichig script, were printed (Rinchinsambuu 1963). 
Modern Mongolian literacy, which is based on official claims about the efficiency, transparency, and scientific precision of, first, Latin, and then, the Cyrillic script (Kapišovská 2005), arose out of the extreme official violence perpetrated by the Revolutionary Party against the Tibetan Buddhist church. Throughout the first half of the 1930s, the Revolutionary Party attempted to exert control over the Buddhist church by enacting educational restrictions and Mongolian language policies (Bawden 1968, 361-369; Natsagdorj 1981, 86-88). These legal and rhetorical strategies were replaced by state violence when, from 1937 through 1939, as reported at the Victims of Political Persecution Memorial Museum in Ulaanbaatar, more than 13,680 lamas were executed (see Baabar 1999, 369) and 615 out of 771 temples were destroyed (Baabar 1999). State violence against the Buddhist church destroyed the dominant cultural, educational, and literacy force in Mongolia, which had focused on Tibetan as the sacred language, gained its authority from its connection to the spiritual traditions of Tibet and India, and connected Mongolians to pre-revolutionary values and allegiances. State violence against these prerevolutionary literacy practices, which included the destruction of Tibetan schools and the immolation and confiscation of sacred texts and other ritual objects (Baabar 1999, 370), had a causal, yet rarely explored, relationship to the emergence of Cyrillicization and the closer adoption of Soviet cultural forms. As Irina Morozova $(2009,106)$ argues, the language policies that made Cyrillic the official script complemented the violence to weaken the cultural potential of the Buddhist Church: "This symbolic event could be characterized as the final blow to the disappearing sangha and the high tradition of Buddhist culture."

Although we do not need to imagine literacy advisors, teachers, and linguists with blood on their hands, readers need to be aware that the project of mass, compulsory literacy was never far from the violence; moreover, its ultimate goal was similar: to fashion a monological, univocal 
society in which Revolutionary Party discourse saturated the public sphere. Modern conceptions of literacy enabled state and party administrators to make its Mongolian subjects—especially rural semi-nomads who did not look like, behave, or talk like members of the socialist proletariat—more governable and "legible" (Scott 1998). The development of a formal, compulsory educational system that dedicated approximately 10 hours per week for language training in Mongolian and in Russian (UNESCO 1971) was the most important official strategy to demonstrate the authority of the Revolutionary Party through literacy. In 1955, for example, the Revolutionary Party decreed that primary education was compulsory for all children (UNESCO 1982), and the interview data from the University of Cambridge Oral History of Twentieth Century Mongolia (2013) substantiate this generalization: in the second half of the twentieth century, participants report fewer examples of older relatives who forbade their children to attend state schools and more examples of children who claimed that their initial intellectual experiences occurred in primary school—not in the home (e.g., Dashdorj Narantsetseg, female participant, b. Ulaanbaatar, 1943). Literacy, in other words, gradually became a resource to be controlled by state authorities within formal state classrooms. The Cultural Campaigns, instituted at the end of the 1950s for the purposes of instilling "hygiene, literacy, and public order" (Tsetsentsolom 2014, 427), were intended, therefore, to reach countryside adults who had not previously participated in formal schooling — who had not, in other words, perhaps experienced a direct intervention with the authority of the Mongolian socialist state.

\section{Oral History}

Oral history is a widespread methodology in literacy studies (Barton and Hamilton 1998; Heath and Street 2008) and is defined, most simply, as "a method of collecting narratives from 
individuals for the purpose of research" (Leavy 2011, 4). Deborah Brandt (2001), for example, conducts structured life history interviews across several generations to suggest the layers of literacy resources, opportunities, and sponsors that are available in particular historical, social, and regional contexts. Because of the fact that oral histories allow participants to provide such rich and local historical and cultural data, this method allows researchers to challenge autonomous, neutral, and ahistorical conceptions of literacy.

This article is based largely on data from the University of Cambridge Oral History of Twentieth Century Mongolia (2013), a free, open-access online database that consists of interviews from approximately 600 participants. By searching for the Mongolian equivalents of such terms as "campaign," "script," "writing," and "alphabet," 41 Khalkha Mongolians were identified, $8.4 \%$ of the total number of Khalkha participants in the University of Cambridge study, whose experiences, both as literacy learners and as teachers, were helpful in understanding literacy development during the Cultural Campaigns. Thirty-two of the participants (78\%) were born between 1920 and 1950, and ten (25\%) of them are female. The majority of the participants formed their literacy experiences outside of Ulaanbaatar and in aimag or sum centers (equivalent to a "county" or "constituency"), or in the countryside. Although the University of Cambridge Oral History includes an impressive range of Mongolian ethnicities, with 20 non-Khalkha groups representing $24 \%$ of the number of participants, this study focuses only on the Khalkha dominant cultural and political group. The decision to reduce the focus solely to the Khalkha ethnic group was made to narrow the focus of the results. Hopefully, future researchers will challenge and complicate the results in this article by focusing on, among others, Buriyats in Northern Mongolian, Kazakhs and other Western Mongolian ethnic groups, and Inner Mongolians (see Bulag 1998; Empson 2011). 
A limitation of relying upon the University of Cambridge Oral History is the fact that literacy itself is rarely an area of direct inquiry, and this study has had to construct literacy practices and narratives from participants' responses to their experiences with the Cultural Campaigns. This study cannot take for granted that the University of Cambridge Oral History project leaders and interviewers ascribed to a social theory of literacy, though, given the close disciplinary alignment between oral histories and social literacies, there is no reason to assume that they would be unsympathetic. The limitation occurs because as literacy becomes more of an expected, everyday, and mass practice, individuals begin to regard it as commonsensical and natural. We stop thinking about reading and writing as social, cultural, and historical forms once we take them for granted and assume, therefore, that literacy is inseparable from formal educational institutions and efficiently measured and represented through statistics (Hamilton 2012). In fact, oral histories can provide provocative opportunities to challenge our assumptions about literacy because they enable researchers to question the canonical historical interpretations and official narratives; in addition to this, oral histories contribute to the archive, which, in the case of Mongolia, is dominated by official narratives, memoirs of elite intellectuals and officials, and canonical histories; unfortunately, little else remains to populate the archive, such as teacher conspectuses, teacher preparation materials, student notebooks, classroom materials, and evaluation reports.

According to Patricia Leavy (2011), the credibility and validity of oral histories are rhetorically determined; researchers use strategies to build the confidence of their readers, including an explicit interpretive methodology, such as grounded theory, as well as triangulation, in which generalizations are supported by other perspectives and documents (Heath and Street 2008). Given the social literacies approach adopted in this study, credibility and validity can also 
be enhanced by showing awareness of how the University of Cambridge Oral History participants' statements and narratives are not neutral and outside of the realms of history and politics. Because of the fact that these interviews were conducted close to twenty years after the collapse of the socialist Mongolian People's Republic, we need to remain mindful of the layers of literacy cultural models - including those from socialist and post-Soviet perspectives, among several others - and rhetorical purposes that may inflect the participants' responses. By way of these interviews, the participants are shaping their lives and beliefs, based upon their own values and commitments to the socialist past and the immediate past of free-market Mongolia as well as upon the actions and identities they want to project to the interviewer, the Western institution sponsoring the study, and a much larger Mongolian audience.

\section{The Cultural Campaigns, Literacy, \& Technologies of Power}

Christopher Kaplonski $(2014,78)$ briefly compares the Cultural Campaigns of the 1930s with those of the 1950s, noting that the latter was "part of a successful drive to collectivize." When comparing these two collectivization movements, researchers have concluded similarly that the second collectivization movement was far more accepted by the semi-nomadic pastoralists and conducted by means of persuasion, social pressure, and economic necessity (e.g., Steiner-Khamsi and Stolpe 2006). In this section, interview data from the University of Cambridge Oral History are synthesized and analyzed to demonstrate how the Cultural Campaigns, which should be understood as working in tandem with the collectivization movement, represented the authority of the Revolutionary Party in ways that pastoralists found acceptable. Though still coercive and intrusive, the goals and methods of the Cultural Campaigns were non-violent. Cultural Campaign administrators relied on technologies of power (Giddens $1985,11)$, rational and modern strategies to make pastoralists identify with the socialist state, 
perform new ways of life, and, operating parallel to the formal education system, adopt a nationalist identity (Kaplonski 1998, 45). These strategies are consistent with those that Scott (1998) identifies as ways for "high modern" states to induce social order, including standardization, regularization, simplification, communication, and urbanization as well as official appeals to progress, efficiency, and development.

In addition to literacy, the other goals of the Cultural Campaigns, consisting of hygiene, health, and propaganda, penetrated the home, classroom, factory, and collective. Literacy or alphabet teachers, in this case, were low-ranking, rural agents for the Revolutionary Party, and worked alongside hygiene inspectors, nurses, and propagandists; in fact, oftentimes, a single individual would act both as the literacy teacher and the propagandist. These four aims of the Cultural Campaigns were grouped together, pointing to the values of Mongolian socialist development, such as modernity, science, and rationalism. They were, above all, "clean" and "new," purified of a pre-revolutionary order, and operated, thus, additionally as "strategies of forgetting" (Buyandelger 2013), ways for Mongolians to shift from the traditional past to the socialist future. In order to embrace the values of Mongolian socialism, common Mongolian herders demonstrated the cleanliness of their homes, their bed linen, and their bodies; they made sure that their blood was clean, meaning that it had been checked and treated for sexual diseases; their dirty, disordered, or backward thinking, furthermore, was treated by propaganda and socialist ideology; finally, their illiteracy — another state of backwardness and primitiveness in terms of Mongolian socialist historiography—was purified by the exposure to the Cyrillic alphabet, another index of modernism, efficiency, transparency, and internationalism. The metanarrative of this society promoted modern values of social order and socialist subjects who possessed clean bodies, clean blood, clean minds, and, of course, clean scripts. 
The following three sections document the technologies of power that circulated through the goals and practices of the Cultural Campaigns. The hygiene campaigns are presented first because they exemplified the direct imposition of state power on the private homes and personal bodies of pastoralists. The Mongolian home, or ger, became the locus of the centralized power; moreover, this private space became public as intimate details about a family's cleanliness were made part of the official record, taking the shape of commendations, for obedient and hygienic families, or shame, for families who failed to perform modern and "clean" ways of living. Similar to the hygiene campaigns, literacy instruction demonstrated the authority of the socialist state in terms of how it was delivered and represented. However, according to several University of Cambridge Oral History participants, there were limits to these technologies of power. Subtle and muted voices resisted literacy instruction, challenging the Revolutionary Party's ability to produce modern and obedient subjectivities and revealing the degree to which the socialist state's authority was based largely on ceremonial power.

\section{The Hygiene Campaigns: Public Homes \& Bodies}

Hygiene was the main and most obvious goal of the Cultural Campaigns, representing the Revolutionary Party's desire to create social order (Nergüi, anonymous male participant, b. Bayanhongor Aimag, 1948). Given the Soviet obsession with hygiene and daily regimens, it is not surprising that the Mongolian Revolutionary Party would eventually adopt these particular strategies of governability, exerting its authority over Mongolian pastoralists by controlling how they cared for their bodies and the intimate spaces of their homes (Rogaski 2004, 7). Historians of Soviet social life have documented the ways in which hygiene articulated appeals to modernity, science, rationality, and hygiene (Kirschenbaum 2000, 67, 70; Starks 2008, 3-4). Soviet ideologists also metaphorically stretched the discourse of hygiene, arguing that clean, 
hygienic bodies invited healthy bodies and rational thinking (Starks 2008, 4) as well as new ways of living that discarded past, polluted lives and traditions (Kirschenbaum 2000, 133). When viewed in this light, hygiene functioned similarly to mass literacy instruction for the socialist Mongolian state: both were modern practices, grounded in efficient sciences-Taylorism and linguistics, respectively — that inculcated social order through such strategies as standardization and categorization. In short, modern hygiene and literacy led to healthy bodies and "clean" minds.

In addition to how hygiene and literacy functioned similarly to promote a modern subjectivity, they were paired together, according to the logic of the Cultural Campaigns, in an analogical relationship. Hygiene and literacy were the two "external," observable Revolutionary Party goals. They possessed a causal relationship with their respective "internal" and less observable goals, health and ideology. Hygiene, associated with physical fitness, time management, and morality, was characterized as having a direct relationship with "health," a euphemism for the prevention of sexually transmitted diseases, which, because of their "secretive" nature, alarmed both Soviet administrators (Starks 2008, 187) and socialist Mongolian officials (Billé 2014). Likewise, literacy, associated with the efficient, modern Cyrillic script, enabled more effective indoctrination into socialist ideology and, furthermore, enabled Mongolian subjects to perform their commitment to this ideology by way of copying, letter writing, reading, and reciting.

Hygiene provided an important opportunity for Cultural Campaign administratorsinspectors, nurses, teachers, and propagandists - to enter the private gers of Mongolian pastoralists, echoing a Soviet practice in the 1930s of government or party officials visiting Russian homes to examine sleeping arrangements, political thinking, religious or cultural icons, 
and cleanliness (Kirschenbaum 2000, 143). In Mongolia, the Cultural Campaigns secured the consent of pastoralists for the state to enter their homes and coerce how they cared for their bodies and minds, which previously had been under the authority of the Buddhist Church (Billé 2014; Kaplonski 2014). Extending the logic of Scott's (1998) focus on high modernism, the ultimate goal was to make the practices and habits of the private space so visible and transparent that it would be undistinguishable from the public space: the aims of private individuals would thoroughly harmonize with those of the state and party (see Heller 1988; Rogaski 2004). Mikhail Heller $(1988,23)$ dramatizes this point in his invocation of Andrei Platonov: “"Man no longer has any time left for a so-called private life, for it has been replaced by governmental and socially useful activity. The state has become his soul."' In Scott's $(1992,128)$ theoretical framework, when private life becomes subsumed by the "public transcript," the official ways in which the state apparatus represents itself, subjects lose the potential to resist authority.

The University of Cambridge Oral History participants document the degree to which state health and hygiene workers attempted to shape a new conception of the public sphere. Danzan Norson (female participant, b. Selenge Aimag, 1928) describes the Cultural Campaign hygiene inspections that started in 1961 in Sükhbaatar City, the aimag capital of Selenge. As a nurse, Norson, along with an inspection team of doctors and nurses, left every Wednesday morning to conduct hygiene and cleanliness checks of local families and maintain records of the inspections (tailan). When the hygiene inspection team entered the home, they immediately inspected the bedding, making sure it was clean and checking whether there were enough sheets and blankets for each family member. The inspection team also checked the kitchen cleaning cloths and determined whether they were cleaned and dried properly. During the inspections, information was provided, such as the type of medication to take for a cold, the benefits of 
following a hygiene regimen, the proper ways to dispose of dirty water, the importance of clearing rubbish from outside the home, and subbotnik opportunities, the "voluntary" Saturday community work projects. Norson's account is similar to those of many other participants. Tseden Dashdamba (male participant, b. Töv Aimag, 1935), who directed the Cultural Campaign in a small sum in Bulgan Aimag, emphasizes the Revolutionary Party policy on personal cleanliness and the inspection of people's nails and whether there were two changes of bedding and underwear for each family member. Other items that were inspected were drinking glasses, toothbrushes, and face and body soap (Yadam Dulamjav, female participant, b. Hovd Aimag, 1936; Damdinsüren Naidansüren, male participant, b. Govi-Altai Aimag, 1949). Baldan Haltar (male participant, b. Dundgovi Aimag, 1938), an education administrator during the Cultural Campaigns, expands the concern of the campaign beyond bedding and towels to the installation of water taps, metal stoves, bathrooms as well as flooring for gers. Not only did the family's ger and immediate yard (khashaa) need to be kept tidy, but, according to one participant, a 50 meter radius around the home (Luvsandorj Khishigee, female participant, b. Selenge Aimag, 1943).

Beyond sum and aimag centers, individual mobile hygiene inspectors traveled on horseback to visit private homes. Shagdar Baasanjav (male participant, b. Bayanhongor Aimag, 1959) recalls the Cultural Campaign beginning in 1969 in Bayantsagaan sum in Bayanhongor Aimag. Departing from the sum center, the hygiene inspector (baitsaagch) traveled on horseback for seven to ten days, visiting about eight families a day, many of whom were separated by considerable distances. The existence and cleanliness of white bedding was the main focus of the inspections, and the inspector counted whether enough blankets, sheets, hand towels, and toothbrushes were available for family members; likewise, the family had to display a towel that was used for washing plates and glasses as well as another towel for washing the cooking pots. 
At the end of the visit, the inspector filled out an overall hygiene evaluation for the family, which was signed by the head of the family. The hygiene evaluation consisted of four categories: excellent (onts), good (sain), average (dund), and poor (muu).

The hygiene inspections were more invasive in certain aimags. In Dundgovi, a doctor served in the role of hygiene inspector. According to Shagdar Luvsandorj (male participant, b. Dornogovi Aimag, 1932), the doctor, immediately after entering the ger, stripped the blankets and sheets off the bed, searching for dirt and lice. The family members then took off their clothes and were again inspected for body lice and dirt and questioned about the last time they took a shower. Family members possessed a ticket, on which was recorded the last time they took a warm shower and viewed a Cultural Campaign propaganda film. Luvsandorj states: "This ticket would be inspected and the person would be ordered to take a bath or watch a film. That's the way the Cultural Campaign was carried out.”

The documentation of these inspection visits produced a public record, open for public discussion at party or collectivist brigade meetings, or displayed in the "red corner" of the brigade center office or the aimag or sum center. For example, Tserendash Namkhainyambuu $(2000,44)$ narrates how collective brigade leaders publicly praised and shamed workers: "The good people were praised, and the bad people were made to stand up and were reprimanded, and lazy young people who neglected their herds were especially made to sweat while they were coerced into promising to improve themselves." In this case, this strategy of publicly commending and shaming workers shows the role of surveillance and documentation, two key strategies of maintaining the authority of the modern state (Giddens 1985). Yet, even though Namkhainyambuu's narrative shows how the actions of pastoralists become a part of the state record, there is more going on here. Namkhainyambuu, who as a champion herder and model 
socialist straddles both traditional and modern-socialist forms of authority, shows how public adulation and shame were also personal dramas between directors and workers. In this case, the directors in Namkhainyambuu's narrative relied both on traditional and modern resources of authority.

The Cultural Campaign practices of praising and shaming continued to vacillate between the modern technologies of surveillance, documentation, and evaluation and traditional Mongolian social practices. Families who had successfully passed the hygiene inspections received the "Cultured Family" title or the "Star" commendation, as well as small gifts, such as bars of soap. On the propaganda bulletin boards at the party or propaganda offices, these clean families were symbolized by a modern image such as an airplane. Yet, in addition to their involvement in these documentary procedures, these successful families were also asked to serve as models for families who received poor evaluations (Baasanjav; Dashdamba; Dulamjav; Norson), encouraging, in effect, more traditional social relationships between families and obviating the direct role of the Revolutionary Party or Cultural Campaign administrators. Moreover, for those individuals and families who failed the hygiene inspections, public shame and the fear of embarrassment were used to induce cooperation and social order. According to Baasanjav, at the end of the inspections, the evaluations were written down, signed by a family member, and then made a part of a public report. In Bayanhongor Aimag, families receiving a poor evaluation had to suspend a wooden image of a pig from their front door, making their uncleanliness visible to other travelers in the area; after three consecutive poor ratings, a fine of 25 Tugriks was collected. In Selenge Aimag, the procedures were the same, though the symbol was different: unhygienic families were depicted by a frog (Norson). Again, the processes involved in inspecting, evaluating, reporting, and publicizing the hygiene results revealed 
modern values and techniques; the emotions of shame and fear, however, reflected a traditional logic.

Public shaming also reached a national scale, a reminder that, for Revolutionary Party administrators, these public evaluations of hygiene promoted a particular type of modern subjectivity and national citizenship identity. The satirical party magazine, The Woodpecker (Tonshuul), printed the names of many of the families who failed the inspections, as well as the names of other individuals who had exhibited inappropriate conduct (dogoldoltoi). Propaganda workers, local government administrators, and local party officials displayed this magazine on their public propaganda notice boards alongside the local evaluations. In formal education settings beyond the Cultural Campaigns, students practiced these potential future national identities, rehearsing similar rituals of public shaming. Students who fared poorly on their daily hygiene inspections had their name recorded in a "joke document," which was then hung in the “joke corner” in the classroom (Luvsanrenchin Dügersüren, male participant, b. Zavkhan Aimag, 1951).

\section{Literacy \& Modern Technologies of Power}

This section explores literacy instruction as a technology of power wielded by the Revolutionary Party during the Cultural Campaigns. If we bear in mind Scott's (1998) strategies for state power, literacy instruction became an important means for making a disparate, decentralized, and dialectically diverse group of semi-nomadic Mongolian herders and pastoral workers far more "legible," controllable, and governable. Their "health, skills and education, longevity, productivity, morals, and family life" (Scott 1998, 91), among other characteristics,

can be categorized, standardized, controlled, and made the subject of planning and statistical planning. According to Giddens $(1985,14)$, this accumulation of information reflects the 
impersonal relationship of surveillance that constitutes how modern nation-states control their subject populations. Literacy instruction, it is important to remember, both acts as a site of surveillance and as a technology of power to perpetuate surveillance, in that it enables the expansion of communication, documentation, and record keeping (Giddens 1985, 174, 179), all of which are necessary for the administrative purposes of the modern state.

Although this section will focus on literacy instruction as a modern technology of power, we need to be mindful of a traditional resource of authority: the Mongolian classroom teacher. Unfortunately, the University of Cambridge Oral History participants offer little detail about their daily experiences as teachers or students during the Cultural Campaign. Based upon what we know about the learning materials, the alphabet-based curriculum, and formal socialist Mongolian classrooms (Steiner-Khamsi and Stolpe 2006), we can assume that the dominant focus of the alphabet classroom was the teacher, who stood at the front, writing and modeling the letters, syllables, words, and sentences — in that particular order — on the board. Students, on the other hand, were passive. They were expected to copy down course materials from the board into their notebooks, memorize them, and repeat and respond to the teacher's commands, either individually or as a whole class. This type of teaching was not necessarily "modern," however, and may have descended from traditional Mongolian teaching, based upon the pedagogy of the Buddhist church (Dreyfus 2003); on the other hand, especially for teachers who were outsiders, without close social ties to families in the area, their authority may have stemmed from their association with the Revolutionary Party; that being said, teachers, as we will see below, questioned how much authority they actually had.

By defining Mongolian pastoralists as an observable, legible population, the Revolutionary Party proposed to use literacy as one strategy for social improvement or 
individual development. One Cultural Campaign slogan exemplified this appeal to individual improvement, which was articulated in terms of the development of the Mongolian nation. Individuals were urged to take an additional educational "step": non-literate people should step towards an elementary level of literacy; those at the elementary level should become intermediate; those at the intermediate should become excellent; those with a primary-school (i.e., four-year) education should strive for a middle-school (i.e., seven-year) education, whereas those with a seven-year education should advance themselves to a ten-year secondary education; finally, those with a secondary degree should obtain a university degree (Luvsandorj). What is striking about this slogan is that it conceptualized the Mongolian state as a mass population, one that was working together by climbing these inter-locking literacy or education steps. Obviously, we need to be cautious about interpreting these state-directed, authoritative exhortations as appeals about personal growth or the development of the private self. Instead, the overall health of the state - in this case, its efficiency, modernization, and social order—was at stake.

The local literacy instruction that took place during the Cultural Campaigns demonstrated the centralized authority of the Revolutionary Party. At local, low-level administrative sites in the countryside, literacy instruction was represented by a range of possibilities, including shortterm alphabet courses, evening classes for workers, summer classes, traveling teachers, and literacy circles (duguilan) or groups (bülgem). Furthermore, as depicted in the popular 1998 film, Shine Üsgiin Bichgiin Bagsh (The New Script Teacher), teachers with as low as a four-year formal education were appointed to teach in rural areas or countryside collectives. Although, as we will see in the following section, this rather haphazard, unsystematic attention to instruction at the local level challenged the goals of governability and the implementation of the technologies of power, it also suggests that local leaders were responsive to the commands and 
decrees of officials at the aimag level, who, in turn, were subject to the decrees and policies emanating from party offices and ministries in Ulaanbaatar. According to a University of Cambridge Oral History participant, who was focusing on the flow of party propaganda, this authority was a centripetal force (tövöös) flowing out from Ulaanbaatar "like a molecule being made up of atoms; propaganda was carried out from Ulaanbaatar to the aimags, from the aimags to the sums, from the sums to the bags [the lowest level of administrative power], from the bags to the families" (Dügersüren). These step-by-step links, which also represented different stages of Revolutionary Party bureaucratic power, allowed little possibility for horizontal interaction among administrators at the local level (see Humphrey and Sneath 1999; Scott 1992, 62; 1998, 75).

Cyrillic, the alphabet of literacy instruction during the Cultural Campaigns, played an important role in the goals of standardization and regularization. It represented the new and modern script, proclaimed by Revolutionary Party elites as the official alphabet in 1941, prompting and then implemented as "alphabetization campaigns" in the 1950s (Grivelet 2001, 77). Cyrillic, as well as the other "new" script, Latin, were depicted as more efficient, orderly, and transparent (Grivelet 2001, 87). Latin, however, was quickly and silently rejected as a possible official script, considered deficient in the requisite number of letters and, obviously, in orienting readers and writers towards a Soviet identity (Kapišovská 2005). Unlike the traditional vertical script, Mongol Bichig, Cyrillic was based upon phonetic principles and, therefore, more efficient to learn and to absorb the terminology of technology and science (Kapišovská 2005). During the Cultural Campaigns, rural adult Mongolians were compelled to purify themselves of the pre-socialist, feudal condition of illiteracy—or Mongol Bichig literacy—and become literate in Cyrillic, which would enable them to identify with modern Soviet internationalism (Morozova 
2002, 38). Philologists have long contended that Mongol Bichig allowed loosely allied, nomadic language communities to represent themselves in a common script, despite local variations in pronunciation (Shagdarsuren 2009, 20). The modern socialist nation-state, however, required the phonetic standardization of Cyrillic, another example of Scott's $(1998,54)$ theory of administrative control, in which "unique" languages and dialects could open up unwanted opportunities of "political autonomy" and "represent a formidable obstacle to state knowledge, let alone colonization, control, manipulation, instruction, or propaganda" (Scott 1998, 72).

Cultural Campaign classroom practices reflected this Cyrillic standardization. After graduating from the temporary literacy courses, adult learners talked about their experiences as "learning their 35 letters," more than likely referencing the "alphabet method," which had dominated the teaching of Mongol Bichig and had, in the Soviet Union, earlier troubled reading researchers (Nazarova 1988). Naidansüren indicates another consequence of this alphabet-based curriculum: a degree of infantilization occurred in these literacy classes. He describes how adults were "taught the 35 letters like a first-grade child sounding out the letter 'a' and learning the shape of the letter." Several textbooks, although intended for the instruction of ethnic Mongolians in northern China in the 1950s, strongly suggest how alphabet-based instructional materials looked during the Cultural Campaigns. The fact that these textbooks included Khalkha Mongolian writers celebrating friendship with the Soviet Union hints that these materials had been intended originally for learners from the Mongolian People's Republic. The New Mongolian Alphabet for the Use of the Education of Cadre Workers (Commission on Script Change 1956) begins with a chart of the Cyrillic letters, their pronunciation (depicted in Cyrillic), their Mongol Bichig equivalents, and examples of their use in Cyrillic. The one-page lessons begin by focusing on vowels, using minimal pairs between the short vowels, /e/ and /i/, 
and between the short /e/ and long /ee/ as well as the short/a/ and the long/aa/. At the eighth lesson, the first consonant is introduced, /v/. Students are immediately asked to discern the difference between /v/ and /b/: "Some of us for ' $v$ ' go and use 'b.' It is necessary to pay attention and to write this down." Students are then provided with minimal pairs of "correct" words and then "wrong" words before being given a list of words that include /v/ and /b/ as well as then short, oftentimes proverb-like sentences that provide examples of the consonant pair in question. The rest of the consonants are taught in this fashion; when the possibility exists of a dialectal variant confounding the standardized Cyrillic spelling — variations previously absorbed by the ambiguity of Mongol Bichig - minimal pairs are used to guide the student towards the Khalkha standard.

Alphabet-based curricula, temporary classes, textbooks, and the minimal pair strategy were only a few of the burgeoning technologies of power expressed by the Revolutionary Party. During the Cultural Campaigns, the control over the countryside population intensified, aided by the installation of electric lighting and electric generators (Nergüi). As Scott (1998, 166-167) documents, electrification was heralded by Lenin as a strategy to centralize power, because of the fact that electricity was so easy to control and measure. Electricity could make rural workers more visible and cast light on any latent pre-revolutionary or capitalist desires. The development of reading infrastructure was also important. The Revolutionary Party media, including newspapers, Mongolian Radio, public lectures, theatrical performances, and documentary films supplemented classroom instruction. Newspapers, in particular Ünen (Truth), served as “textbooks" for literacy teachers and party propagandists — again, oftentimes, the same individual held both positions — and featured didactic "lectures" about party policy (Chultem Tserendejid, female participant, b. Bulgan Aimag, 1946). Party newspapers also substituted for the informal, 
oral networks of information and gossip that existed - and continued to exist - among travelers and distant relatives and friends. According to Jügder Dashochir (male participant, b. Hentii Aimag, 1925), the traveling propagandist represented the Revolutionary Party in the countryside. For every ten homes, a propagandist (orkhiin ukhuulagch) checked on the newspapers that the family members were reading, determined whether they needed any new newspapers, distributed mail, and exchanged news. The highly centralized Mongol Radio repeated the propaganda of newspapers and compulsory workplace lectures and, beginning at six o'clock every evening, broadcasted Cultural Campaign programs such as the "Cultural Radio News" (Tserendejid). Documentary films, shown in mobile cinemas or permanent cultural palaces in aimag or sum centers, also circulated the propaganda of the Cultural Campaigns. For instance, Lhagva-Ochir Tseden-Ish (male participant, b. Hovsgol Aimag, 1960) recalls documentaries about the liberation of Western Mongolia from the Manchu Empire and the big-little brother relationship between the Soviet Union and Mongolia.

Among other Soviet institutions that were imported to Mongolia, the sum- or aimag-level library also operated alongside the Cultural Campaigns to define the rural population in terms of literacy-related categories. In the late 1960s, in Sükhbaatar Aimag, Baldan Büjee (female participant, b. Sükhbaatar Aimag, 1948) began working as the sum librarian. She depicts her responsibilities as largely centered around meeting the Revolutionary Party's ideological goals, and she placed herself, in her role as librarian, along with the director of the local cultural club and the film projectionist, as the three local party administrators who disseminated party propaganda. Related to her librarian duties, Büjee organized dances and other cultural events and ran several study circles for the Revolutionary Party and the sum-level industrial union, during which she gave short quizzes on party events as well as the opinions and proclamations of 
specific party leaders. Beyond her direct role as a spokesperson for party ideology, Büjee shaped the reading values of library patrons and restricted their choices. When patrons entered the library, she introduced them to party-approved materials, showed them the party- and aimaglevel newspapers, and talked to them about recent party resolutions and the comments of party leaders. She also kept records on the patrons, dividing them into three age groups: 8-16, 16-40, and over 40. In addition to the number of visitors, their age ranges, and their sex, Büjee collected data on how many books and what type of books they checked out. Despite the fact that Büjee does not indicate what was done with these statistics and whether a patron's choices had political consequences, what was important was the fact that these statistics were compiled in the first place. Categories were constructed, based on sex and age, which could then be correlated to readership proclivities and interests. Furthermore, Büjee followed the genre logic of the socialist Mongolian state, narrowly categorizing the library collection into four possible genres: state, school, literary, or cultural. This classification in itself represents state power and, in particular, its ability to codify texts and sanction the ways in which readers were to define them.

A final example of how the modern technologies of power were expressed through literacy is the representation of reading strategies. Reading was related to self-development-not to be confused with individual development or empowerment: in this case, the development of the self was analogous with the development of the modern socialist state. A 1970 article in Ukhuulagchiin Övriin Devter (Propagandist's Notebook), which disseminated methodology and party-related news to countryside party propagandists, depicts reading as a highly rational and methodical process. Providing advice to adult readers who want to "work with books," this article, "Part II: What Should Readers Pay Attention To?" (Galsanpuntsag 1970), emphasizes the need for adults to develop themselves outside of a formal educational setting — what North 
American educators now refer to as "lifelong learning" (see Steiner Khamsi and Stolpe 2006). Readers should adopt a definite plan to make their reading more efficient. The article suggests such strategies as getting acquainted with the table of contents; understanding the book's purpose, methods, and "material characteristics"; and making decisions about what parts of the book to pay more attention to and take notes on. Readers need, furthermore, to develop their ability to read silently and faster and to practice different stages of reading and notetaking. Among many other suggestions, readers should consolidate their understanding of a book by talking about it with others and not wasting a moment of their free time; readers, in other words, need to possess rational and moral characters, pay attention to time schedules, and follow daily regimens (see Kelly 2006). Reading literature, consequently, should not be a leisurely activity. The literary work should meet a significant purpose, such as realizing the "good and bad differences in the world" (Galsanpuntsag 1970, 30).

\section{Subtle Strategies of Resistance?}

As the Cultural Campaigns expanded the authority of the Revolutionary Party to the Mongolian countryside, the lack of urbanization, transportation, communication systems, as well as the vast size of the territory and low population density, made such modern strategies as surveillance and documentation impractical (see Giddens 1985). In short, the Revolutionary Party could not completely isolate their pastoral subjects from each other (see Scott 1992, 62) and eliminate the potential for resistant texts, conversations, and actions. Interestingly enough, the University of Cambridge Oral History participants rehearsed several "hidden transcripts," Scott's (1992) term for the utterances and performances that responded to and resisted the dominance of the state. These "hidden transcripts" were subtle and muted, expressed by humor, mocking sarcasm, resignation, and apathy. For example, Naidan Suuri (male participant, b. 
Bulgan Aimag, 1929) depicts an example of how the official sanctity of the Cultural Campaign inspection visits was appropriated for the benefit of the pastoral families. Suuri's family greeted the state inspectors by building social ties with them and creating a festive atmosphere. Family members displayed their newest pastoral products and dressed in their finest clothes and white smocks (khalaaz). Despite this high level of consent and commitment to the goals of the Cultural Campaigns, Suuri hints at a subtle form of pragmatic resistance. As soon as the inspectors left, family members quit their performance, took off their state-sanctioned clothes, and quickly put away their products. Suuri's account is one of the few performative examples of subtle resistance, one that successfully co-opts the technologies of power exerted by Cultural Campaign administrators, playing with the codes of traditional hospitality and official politeness in order to conceal their traditional—and possibly "unhygienic"—practices.

Unlike such mass literacy movements as the Cuban Literacy Campaign (Rempel 2012) or, for that matter, the mass and highly scripted reading and penmanship instruction in the United States throughout the 1950s and 1960s (Brandt 2001, 93), the technologies of power employed by the Mongolian socialist state were far from efficient and remained fragmented and dependent on the local capabilities of sum- or aimag-level directors. In the literacy classroom, countryside adult learners countered the authority of the teacher through such strategies as apathy and humor. Indeed, given the fact that literacy teachers may have been younger than their students and possessed little teaching experience, they may have felt little authority in the first place. Suuri's experiences as a literacy teacher demonstrate how the social decorum idealized by Cultural Campaign administrators could be challenged in local classrooms far from the center of state power. As a low-level bag communist party secretary, Suuri taught Cyrillic alphabet classes to older adults. While he modeled such common household words as "cooking pot," "bucket," and 
"spoon" at the board, his students laughed, demanding that he show them how to spell such words as a "lamb's fangs" or a "camel's molars" or translate various Tibetan words into Mongolian Cyrillic. Once, as Suuri demonstrated how to combine vowels and consonants to make syllables, he spelled /al/, a vulgar word, prompting his students to break out in laughter and react, "Oh my god! He just asked us to write down 'al.' What a bad word to write down."

Tseden Tseren (female participant, b. Dundgovi Aimag, 1929) taught Cyrillic to large classes of rural adults throughout the western aimags. Tseren's skepticism about the effectiveness of her temporary courses again counters the efficiency and social order imagined by Cultural Campaign officials. Tseren reports, "Around 40 old folks would come riding up on horses and camels. The old women could not see and could only write with a magnifying glass. The men would smoke and glance from here to there. How they learned no one will ever know. Then, the next group of 40 would arrive." A final example is offered by Dondov Namkhai (male participant, b. Bulgan aimag, 1945), who worked as a traveling literacy teacher for a collective in the late 1960s, teaching adults as well as adolescents whose formal education had been interrupted. These students, according to Namkhai, were extremely apathetic and were unable to perceive how literacy training could provide them with alternative life opportunities beyond herding and pastoral work. Regardless of their performance or attitude, Namkhai's students still received their certificate for their "literacy circle" participation.

In addition to student resistance, the lack of assessment that Namkhai implies in his experience as a temporary alphabet teacher highlights an additional reason why Cultural Campaign administrators failed to make such literacy experiences more than ceremonial expressions of state authority. Despite the fact that Mongolian precedents for writing assessment procedures existed in the 1950s and 1960s, learners were typically "assessed" solely on the basis 
of their participation - a crude performance statistic that provided little information about these new modern subjects. Incipient assessment procedures existed such as dictation. For example, Oros Dashravdan (male participant, b. Bayanhongor, 1935), when applying for a tractor driving position, recalls a brief 70-100 word dictation : "If there weren't too many mistakes, you would pass; if there were too many mistakes, you would fail.” In addition to dictation, Mongolian military institutions held placement and entrance examinations, which, from 1960, included memorization exercises, math puzzles, and multiple-choice questions (Soli Sandag, male participant, b. Hovd Aimag, 1939). In a different course in the 1950s, Dashravdan describes the nonchalant assessment procedures practiced by administrators: "[You would] write something down, think about basic arithmetic and, having written your name down, you would be considered literate, and then you received a literacy certificate." The tenor of Dashravdan's explanation hints at, quite possibly, a strategy of resistance in itself: low-level state administrators, who were compelled to produce and document modern subjects - in this case, literate workers — did so in the most expedient and practical way possible: students were certified by way of their attendance and with little regard of their performance.

\section{Conclusion}

In Ulaanbaatar, the sprawling capital city of Mongolia, the socialist past is gradually being erased or reappropriated. The iconic Lenin statue that had stood in front of the Ulaanbaatar Hotel since 1954 was recently dismantled; in its place now stands a monument for Dashdorjiin Natsagdorj, who also represents a socialist Mongolian construction. Yet, as Mongolia’s first canonical modern poet who passed away directly before the violent purges in the late 1930s, Natsagdorj offers a muted challenge to that authoritarian power and can be conveniently reappropriated as a modern national poet for post-socialist audiences (see Kaplonski 2004). The 
large Sükhbaatar Square, which once embodied the center of Mongolian socialist power, has now been officially renamed after Chinggis Khan, continuing a process noted by Humphrey (1992) of replacing socialist symbols with those from the rhetoric of tradition and the dimlyunderstood distant past. Furthermore, for many Mongolians, the socialist past represents a Soviet "mistake" (Steiner-Khamsi and Stolpe 2006, 39), delaying the economic and political development of the country and separating Mongolians for many decades from their religious beliefs and traditions (Buyandelger 2013). The Victims of Political Persecution Memorial Museum in Ulaanbaatar exemplifies Mongolians' ambivalence towards this unsavory past. Adjacent to the rapid development of downtown Ulaanbaatar, will this ramshackle and rarelyvisited museum devoted to those who were violently suppressed under modern socialist power survive such post-modern gentrification?

For Asian Studies scholars, these strategies of erasure, renaming, and reappropriation are not surprising (e.g., Hansen 2001). Rapid urbanization, globalization, dramatic shifts in ethnic identity formation, as well as they dizzying recent flows of capital, consumer goods, technology, media, cultural signs, and, of course, people make it difficult to recognize the relevance of history. Yet, such ahistorical "snapshot" analyses of social and cultural practices - those that provide only an immediate and frozen perspective - may make recent dominant economic shifts, such as that of Western globalization, appear natural and inevitable (Blommaert 2010), rendering potential political interruptions or rhetorical challenges more difficult to imagine. Additionally, such ahistorical approaches sever social practices and cultural beliefs from their origins (Billé 2014; Tsetsentsolmon 2014) — or, at least, from the possibilities of denaturalizing and complicating the genealogies of these practices. According to Brandt (2001), justifying a historical approach to literacy studies, distant values and practices related to reading and writing 
persist throughout periods of dramatic social change, becoming sedimented, layers of literacy practices lying across other "traditional" practices, yet without disappearing. In the case of Mongolia and other Asian countries experiencing massive social change, historical literacy practices such as those emanating from the authority of the socialist state in the Cultural Campaigns, may complicate, shape, or resist such attitudes or practices that appear commonsensical only in the context of post-socialist globalization.

\section{References}

Arnove, Robert F., and Harvey J. Graff. 1987. National Literacy Campaigns: Historical and Comparative Perspectives. New York: Plenum.

Baabar. 1999. Twentieth Century Mongolia. Cambridge: White Horse Press.

Barton, David and Mary Hamilton. 1998. Local Literacies: Reading and Writing in One Community. London: Routledge.

Bawden, Charles R. 1968. The Modern History of Mongolia. London: Weidenfeld \& Nicolson. Bazerman, Charles, and Paul Rogers. 2008. "Writing and Secular Knowledge Outside Modern European Institutions.” In Handbook of Research on Writing, ed. Charles Bazerman, 143156. New York: Lawrence Erlbaum.

Best, Shaun. 2002. Introduction to Politics and Society. Thousand Oaks, CA: Sage Publications. Billé, Franck. 2014. Sinophobia: Anxiety, Violence, and the Making of Mongolian Identity. Honolulu, HI: University of Hawai'i Press.

Blommaert, Jan. 2010. The Sociolinguistics of Globalization. Cambridge: Cambridge University Press.

Brandt, Deborah. 2001. Literacy in American Lives. Cambridge: Cambridge University Press. 
Brooks, Jeffrey. 2000. Thank You, Comrade Stalin! Soviet Public Culture from Revolution to Cold War. Princeton: Princeton University Press.

Bulag, Uradyn E. 1998. Nationalism and Hybridity in Mongolia. New York: Oxford University Press.

Buyandelger, Manduhai. 2013. Tragic Spirits: Shamanism, Memory, and Gender in Contemporary Mongolia. Chicago, IL: The University of Chicago Press.

Cheng, Yinghong. 2008. Creating the "New Man": From Enlightenment Ideals to Socialist Realities. Honolulu, HI: University of Hawai’i Press.

Commission on Script Change. 1956. Kadrchuudig Bolovsruulakhad Khereglekh Mongol Shine Üsgiin Üseglel [Primer for Cadre Training in the New Mongolian Script]. Khokhkhot: Inner Mongolian People's Publication Commission.

Connery, Christopher Leigh. 1999. The Empire of the Text. Lanham, MD: Rowman \& Littlefield. Crisp, Simon. 1989. “Soviet Planning since 1917-53.” In Language Planning in the Soviet Union, ed. Michael Kirkwood, 23-45. London: Macmillan.

Crossley, Pamela K. 1994. "Manchu Education.” In Education and Society in Late Imperial China, 1600-1900, ed. Benjamin A. Elman and Alexander Woodside, 340-78. Berkeley, CA: University of California Press.

Dreyfus, Georges B. J. 2003. The Sound of Two Hands Clapping: The Education of a Tibetan Buddhist Monk. Berkeley: University of California Press.

Eklof, Ben. 1987. “Russian Literacy Campaigns, 1861-1939.” In National Literacy Campaigns, ed. Robert F. Arnove and Harvey J. Graff, 123-45. New York: Plenum.

Empson, Rebecca. 2011. Harnessing Fortune: Personhood, Memory, and Place in Mongolia. Oxford: Oxford University Press. 
Foucault, Michel. 1991. “Governmentality.” In The Foucault Effect: Studies in Governmentality, ed. Graham Burchell, Colin Gordon, and Peter Miller, 87-104. Chicago, IL: University of Chicago Press.

Galsanpuntsag, D. 1970. “Nom, Nomin San, Unshigch. Khoyor: Unshigch Yuu Ankhaarakh Ve?” [Books, Libraries, and Readers. Part II: What Should Readers Pay Attention To?] Ukhuulagchiin Övriin Devter [The Propagandist's Notebook]. 18 (September): 27-30.

Gataullina, L.M. 1977. “Education and Cultural affairs. Mongolian People's Republic.” In Great Soviet Encyclopedia, 3rd ed., 16:505. New York: Macmillan.

Gee, James Paul. 2012. Social Linguistics and Literacies: Ideology in Discourses. New York: Routledge.

Giddens, Anthony. 1985. A Contemporary Critique of Historical Materialism. Vol. 2: The Nation-State and Violence. Cambridge: Polity Press.

Gill, Graeme J. 2011. Symbols and Legitimacy in Soviet Politics. Cambridge: Cambridge University Press.

Graff, Harvey J. 1979. The Literacy Myth: Cultural Integration and Social Structure in the Nineteenth Century. New York: Academic Press.

----. 2011. Literacy Myths, Legacies, \& Lessons: New Studies on Literacy. New Brunswick, NJ: Transaction Publishers.

Grivelet, Stéphane. 2001. "Digraphia in Mongolia.” International Journal of the Sociology of Language 150: 75-93.

Hamilton, Mary. 2012. Literacy and the Politics of Representation. London: Routledge. Hansen, Thomas. 2001. Wages of Violence: Naming and Identity in Postcolonial Bombay. Princeton, NJ: Princeton University Press. 
Heath, Shirley Brice. 1983. Ways with Words: Language, Life, and Work in Communities and Classrooms. Cambridge: Cambridge University Press.

Heath, Shirley Brice, and Brian V. Street. 2008. On Ethnography: Approaches to Language and Literacy Research. New York: Teachers College Press.

Heller, Mikhail. 1988. Cogs in the Wheel: The Formation of Soviet Man. New York: Knopf.. Humphrey, Caroline. 1992. "The Moral Authority of the Past in Post-Socialist Mongolia." Religion, State and Society 20 (3-4): 375-89.

Humphrey, Caroline, and David Sneath. 1999. The End of Nomadism? Society, State, and the Environment in Inner Asia. Durham, NC: Duke University Press.

Kapišovská, Veronica. 2005. “Language Planning in Mongolia I.” Mongolica Pragensia, 55-83.

Kaplonski, Christopher. 1998. "Creating National Identity in Socialist Mongolia.” Central Asian Survey 17(1): 35-49.

----. 2004. Truth, History and Politics in Mongolia: The Memory of Heroes. London: Routledge.

----. 2014. The Lama Question: Violence, Sovereignty, and Exception in Early Socialist Mongolia. Honolulu, HI: University of Hawai'i Press.

Kelly, Catriona. 2006. "Shaping the "Future Race." In Everyday Life in Early Soviet Russia: Taking the Revolution Inside, ed. Christina Kiaer and Eric Naiman, 256-81. Bloomington: Indiana University Press.

Kirschenbaum, Lisa A. 2000. Small Comrades: Revolutionizing Childhood in Soviet Russia, 1917-1932. New York: Routledge.

Leavy, Patricia. 2011. Oral History. New York: Oxford University Press.

Lewin, Moshe. 1994. The Making of the Soviet System: Essays in the Social History of Interwar Russia. New York: New Press. 
Marzluf, Phillip. 2015. “The Pastoral Home School: Rural, Vernacular, and Grassroots Literacies in Early Soviet Mongolia." Central Asian Survey 34(2): 204-18.

Morozova, Irina Y. 2002. The Comintern and Revolution in Mongolia. Cambridge: White Horse Press.

----. 2009. Socialist Revolutions in Asia: The Social History of Mongolia in the 20th Century. New York: Routledge.

Namkhainyambuu, Tserendash. 2000. Bounty from the Sheep: Autobiography of a Herdsman. Translated by Mary Rossabi. Cambridge: White Horse Press.

Natsagdorj, Sh. 1981. BNMAUin Soyolin Tü̈kh [The Cultural History of the Mongolian People's Republic]. Ulaanbaatar: State Publishers.

Nazarova, L.K. 1988. "An Outline of the History of the Methods of Teaching Literacy in Soviet Russia, 1917-1947.” In Cognitive Psychology And Reading In The USSR, ed. John Downing, 37-65. Amsterdam: Elsevier.

Oral History of Twentieth Century Mongolia. 2013. University of Cambridge. Mongolia and Inner Asia Studies Unit. http://amantuuh.socanth.cam.ac.uk/.

Rawski, Evelyn Sakakida. 1979. Education and Popular Literacy in Ch'ing China. Ann Arbor, MI: University of Michigan Press.

Rempel, Chris. 2012. “The 1961 Cuban National Literacy Campaign: Creating a New Citizen.” Kansas State University. Department of English. Unpublished manuscript.

Rinchinsambuu, G. 1963. Mongol Ulsad 1913-1944 Ond Khevlesen Mongol Nomin Bürtgel [Record of Mongolian Books Published in Mongolia, 1913-1944]. Ulaanbaatar: Academy of Sciences. 
Rogaski, Ruth. 2004. Hygienic Modernity: Meanings of Health and Disease in Treaty-Port China. Berkeley, CA: University of California Press.

Sambuu, Jamsrangiin. 2010. Herdsman to Statesman: The Autobiography of Jamsrangiin Sambuu of Mongolia. Translated by Mary Rossabi. Lanham, MD: Rowman \& Littlefield.

Scott, James C. 1992. Domination and the Arts of Resistance: Hidden Transcripts. New Haven, CT: Yale University Press.

---- 1998. Seeing like a State: How Certain Schemes to Improve the Human Condition Have Failed. New Haven, CT: Yale University Press.

Shagdarsuren, Ts. 2009. "A Short Survey of the Scripts Used by the Mongols (The Place of Mongolian Script Among Other 'Mongol' Scripts).” Mongolo-Tibetica Pragensia 2(1): $17-27$.

Smith, Michael G. 1998. Language and Power in the Creation of the USSR, 1917-1953. Berlin: Mouton de Gruyter.

Starks, Tricia. 2008. Body Soviet: Propaganda, Hygiene, and the Revolutionary State. Madison, WI: University of Wisconsin Press.

Steiner-Khamsi, Gita, and Ines Stolpe. 2006. Educational Import: Local Encounters with Global Forces in Mongolia. New York: Palgrave Macmillan.

Street, Brian V. 1985. Literacy in Theory and Practice. Cambridge: Cambridge University Press.

----. 1995. Social Literacies: Critical Approaches to Literacy in Development, Ethnography and Education. London: Longman.

Stuckey, Elspeth. 1990. The Violence of Literacy. Portsmouth, NH: Boynton/Cook. Tsetsentsolmon, Baatarnaran. 2014. "The 'Gong Beat' against the 'Uncultured': Contested Notions of Culture and Civilization in Mongolia." Asian Ethnicity 15(4): 422-38. 
UNESCO. 1971. Education in the Mongolian People's Republic. UNESCO: Bangkok.

----. 1982. Cultural Policy in the Mongolian People's Republic: A Study Prepared under the Auspices of the National Commission for UNESCO. UNESCO: Paris. 